\title{
The Effects of Specific Exercise Program on Anthropome- tric Characteristics and Motor Abilities of Preschool Children
}

\author{
Efectos del Programa de Ejercicios Específicos sobre las Características Antropométricas \\ y las Habilidades Motrices de los Niños de Edad Preescolar
}

Stupar, D. ${ }^{\text {; }}$ Popovic, B. ${ }^{2}$; Romanov, R. ${ }^{1}$; Jankovic, M. ${ }^{3}$; Jezdimirovic, T. ${ }^{2}$ \& Medjedovic, B. ${ }^{2}$

STUPAR, D.; POPOVIC, B.; ROMANOV, R.; JANKOVIC, M.; JEZDIMIROVIC, T. \& MEDJEDOVIC, B. The effects of specific exercise program on anthropometric characteristics and motor abilities of preschool children. Int. J. Morphol., 35(3):1050-1057, 2017.

SUMMARY: In order to determine the effects of specific exercise program on anthropometric characteristics and motor abilities of preschool children, a battery of eight anthropometric measures and 7 motor tests were applied. The current study was conducted on a sample of 60 preschoolers ( 31 in the experimental and 29 in the control group), aged 4 to 5 . They were the respondents in the project implemented by the Faculty of Sport and Physical Education in Novi Sad. The obtained data was analyzed by multivariate analysis of covariance (MANCOVA). It can be concluded that the application of experimental and control models of exercise resulted in substantial improvement of certain motor skills in the experimental group compared to the control group. In regard to the anthropometry there was no statistically significant difference between the groups. In fact, the practical value of this work is to analyze the model of kinetic activities, which as such can be applied to all clubs and schools that work with children of preschool and early school age.

KEY WORDS: Anthropometric measures; Motor abilities; Preschool age; Sports school.

\section{INTRODUCTION}

Motor skills of children, youth and people are affected by different structural features that define them as a bio-psycho-social-integrated being (Lepes et al., 2014). Preschool age is the most important period in the formation of the whole personality of man, because learning a variety of modifications and adjustments to various situations in life comes later (Bala, 2002). Motor functioning of young children is the general type (Ismail \& Gruber, 1971; Bala, 1981), which means that in this age there are no differentiated motor skills (children respond with their whole body in motor rhythm). Moreover, a defining feature of preschool age is emphasized and conspicuous integral development, where the domains of child development (physical, motor, cognitive, emotional, etc.) are closely related. Anthropometric characteristics are the variables that that can be measured by anthropometric instruments. They can be measured objectively (body height, leg length, chest circumference and other). Morphological latent anthropometric dimensions are dimensions that cannot be measured, but their existence is determined by mathematical and statistical procedures which contain condensation and reduction obtained on the basis of the measured anthropometric variables (Bala, 2007). Anthropometric measurements are performed to evaluate and monitor the growth of children. Information about the growth (height and weight) is often used as indicators of health status and nutritional status of children, as well as the evaluation of their rate of growth and development. The growth and the development of activities , in addition to genetic factors, living conditions, physical activity and physiological processes, anthropometric monitoring provides information about the effects of these factors, which can be compared with some existing standards for boys and girls of the appropriate chronological age. Anthropometric characteristics and motor abilities of children are the subject of many researchers (Stupar, 2012).

\section{MATERIAL AND METHOD}

The sample consisted of children aged 4 to 5 , who have been tested in multi-year projects by the Faculty of Sport and Physical Education in Novi Sad, Serbia. The schedule of the samples of the respondents is given in Table I.

\footnotetext{
${ }^{1}$ Faculty of Sport and Tourism, Radnicka 30 A, Novi Sad, Educons University, Serbia.

${ }^{2}$ Faculty of Sport and Physical Education, Lovcenska 16, Novi Sad, University of Novi Sad, Serbia.

${ }^{3}$ College of Professional Studies in Education of Teachers, Petra Drapsina 8, Novi Sad, Serbia.
} 
Table I. The samples of the respondents.

\begin{tabular}{|c|c|}
\hline $\begin{array}{l}\text { The experimental group } \\
\text { ( Sports School ) }\end{array}$ & $\begin{array}{l}\text { The control groups } \\
\text { (Kindergarten "Petar Pan") }\end{array}$ \\
\hline$E$ - The experimental group (generation & $C$ - The control group, generation $2009 / 2010$ ) \\
\hline $\begin{array}{l}\text { 2009/2010.), The sample of respondents }=31 \\
\text { children }\end{array}$ & The sample of respondents $=29$ children \\
\hline \multicolumn{2}{|c|}{$\begin{array}{l}\text { The total sample of respondents } \\
=60 \text { children aged } 4 \text { to } 5\end{array}$} \\
\hline
\end{tabular}

Recent studies (Bala, 1981) indicate that these measurements, in the case of children, cover a two-dimensional model of morphological dimensions: the dimensionality and voluminosity of the skeleton and subcutaneous adipose tissue. The manner and conditions under which the measuring took place were in accordance with the recommendations of the International Biological Program - IBP (Lohman et al., 1988).

The variables of anthropometric measures were as follows:

- for assessment of skeleton dimensionality: 1) body height (cm), was measured using anthropometry according to Martin.

Table II. Plan and program of sports activities in "Sport school".

\section{September}

Initial testing (motor abilities and morphological characteristics) - 2 classes; Athletics (walking and running, stand-up start and block start) - 2 classes; Gymnastics (candles, bridge, string) - 2 classes; Sports Games (indoor soccer) - 1 class; Group games (dodge ball) - 1 class. ; Swimming - 4 classes.

Athletics (throwing balls, vortex) - 3 classes; Gymnastics (roll forwards, backwards somersault) - 2 classes; Sports Games (mini basketball) - 2 classes; Group games (with rope) - $\mathbf{2}$ classes; Combat sports (wrestling, judo) - 2 classes; Swimming -4 classes.

January

Athletics (walking and running, stand-up start and block start) - 2 classes; Gymnastics (candles, bridge, string) - 2 classes; Sports Games (indoor soccer) - 2 classes; Group games (dodge ball) - 2 classes; Swimming -4 classes.

March
Athletics (throwing balls, vortex) - 3 classes; Gymnastics (roll forwards, backwards somersault) - 3 classes; Sports Games (mini basketball) - 2 classes; Group games (with rope) - 2 classes; Combat sports (wrestling, judo) - 2 classes; Swimming $\mathbf{- 4}$ classes

\section{May}

Final testing (motor abilities and morphological characteristics) - 2 classes; Athletics (running, throwing, jumping repetition) - $\mathbf{3}$ classes; Sports Games (outdoor soccer)- 2classes; Swimming $\mathbf{- 4}$ classes
- for assessment of skeleton voluminosity and subcutaneous adipose tissue: - for assessment of voluminosity and balance body mass - 2) body mass, was measured using, 3) circumference of the chest (chest girth) (medium), 4) circumference of the upper arm (mid-arm girth) (in a relaxed position), 5) circumference of the lower arm (forearm girth); for assessment of subcutaneous adipose tissue -6 ) abdominal skin fold, 7) skin fold of the back (subscapular skin fold) and 8) skin fold on the upper arm (triceps skin fold).

The battery of motor tests was based on the experience with adult subjects, modified for young children (Bala et al., 2002) and was based on the model of motor abilities of older children and adolescents (Kurelic et al.(1975). The following motor ability tests were utilized:

\section{October}

Athletics (the standing long jump and start-up, scissor jumps, jumps over a hurdle and ladder) - $\mathbf{2}$ classes; Gymnastics (beams, scales) - $\mathbf{2}$ classes; Sports Games (mini-soccer) - 2 classes; Combat sports (wrestling, karate) - 1 class; Traditional dances - 1 class; Swimming $\mathbf{- 4}$ classes.

December
Athletics (running, throwing, jumping repetition) - 2 classes; Gymnastics (a handstand with the head against the wall) -2 classes; Sports Games (mini volleyball with balloons) - $\mathbf{2}$ classes; Traditional dances- $\mathbf{2}$ classes; Swimming $\mathbf{- 4}$ classes.

February

Athletics (the standing long jump and start-up, scissor jumps, jumps over a hurdle and ladder) - $\mathbf{2}$ classes; Gymnastics (beams, scales) - $\mathbf{2}$ classes; Sports Games (mini-soccer) - 2 classes; Combat sports (wrestling, karate) - 2 classes; Swimming $\mathbf{- 4}$ classes.

Athletics (running, throwing, jumping repetition) - 3 classes; Gymnastics (a handstand with the head against the wall) 3 classes; Sports Games (mini volleyball with balloons) - 2 classes; Traditional dances

Swimming -4 classes

Swimming was optional.

From the $1^{\text {st }}$ of June to the $1^{\text {st }}$ of September -free time 
1) $20 \mathrm{~m}$ dash - to estimate running speed,2) Obstacle course backwards - to estimate coordination,

3) Arm plate tapping - to estimate frequency of simple movements,

4) Seated straddle stretch - to estimate flexibility,

5) Standing broad jump -to estimate explosive strength

6) Bent-arm hang - to estimate static strength of the arms,

7) Sit-ups - to estimate repetitive strength of the trunk.

The main objective of working with children in the "Sports School" was to develop their motor skills, broadly, their motor behavior, as well as the posture of the body, by various means, physical exercises, but without competitions. During the work with the children, testing their motor skills, measuring anthropometric characteristics and control of posture is performed as well as their health status and psychological development (Bala, 2002). Trainings were conducted for one hour, twice a week, from September the 1st, 2009 to June the 1st 2010 and included all sports activities (Table II).

The Preschool Program for Physical Education (Kamenov, 1995) is included in the Regulations on the principles of preschool program, with defined objectives and content of activities for physical development, mastering the skills of movement and strengthening the health of children.

Only those children who have trained for nine consecutive months and who have met the health requirements were taken into account.
Statistical analyses: The results were analyzed by the SPSS 17.0. Statistical package (Statistical Package of Social Sciences - for Windows). The basic central and dispersion parameters (arithmetic mean (M) and standard deviation (SD) were calculated for each motor test and each group of participants. A multivariate analysis of variance (MANOVA) was used to determine the differences between the groups at the initial and final measuring for each group, while the univariate analysis of variance (ANOVA) was applied for the assessment of individual differences in motor variables. The T-test for the dependent samples was applied to determine the differences within each group at the initial and final measuring. The multivariate analysis of covariance (MANCOVA) was applied in order to determine the effects of the treatment on the transformation of motor skills between groups of participants in each age group, while the univariate analysis of covariance (ANCOVA) was applied in order to assess the individual differences in motor variables.

\section{RESULTS}

The results of multivariate analysis of variance for eight anthropometric characteristics for initial measuring, with the level of significance of $\mathrm{p}=0.02$ indicates that there was statistically significant differences between the two groups. Only variables Circumference of the upper arm and Skin fold of the upper arm have achieved statistically significant results differences in favor of the experimental group.

Table III. The results of univariate and multivariate analysis of variance of anthropometric characteristics between the experimental (E) and control (C) group at the initial measurement (generation 2009/2010).

\begin{tabular}{|c|c|c|c|c|c|c|c|c|c|}
\hline \multirow{2}{*}{ VARIABLES } & \multicolumn{5}{|c|}{ INITIAL } & \multicolumn{4}{|c|}{ FINAL } \\
\hline & $\mathbf{G}$ & $\mathbf{A M}$ & $\mathbf{S}$ & $\mathbf{F}$ & p & AM & $\mathbf{S}$ & f & p \\
\hline \multirow{3}{*}{ Height (cm) } & $\mathrm{E}$ & 111.48 & 4.81 & \multirow{2}{*}{0.00} & \multirow[b]{2}{*}{0.97} & 116.31 & 5.14 & \multirow[b]{2}{*}{0.62} & \multirow[b]{2}{*}{0.43} \\
\hline & $\mathrm{C}$ & 111.42 & 579 & & & 115.19 & 5.86 & & \\
\hline & $\mathrm{E}$ & $\begin{array}{c}111.42 \\
19.95\end{array}$ & 2.93 & \multirow[b]{2}{*}{0.03} & \multirow[b]{2}{*}{0.87} & 21.68 & 3.28 & \multirow[b]{2}{*}{0.45} & \multirow[b]{2}{*}{0.51} \\
\hline Body mass (kg) & $\mathrm{C}$ & 1983 & 2.34 & & & 21.17 & 2.56 & & \\
\hline \multirow[b]{2}{*}{ Circumference of the chest $(\mathrm{cm})$} & $\mathrm{E}$ & $\begin{array}{l}19.03 \\
55.67\end{array}$ & $\begin{array}{l}2.54 \\
3.27\end{array}$ & \multirow[b]{2}{*}{0.09} & \multirow[b]{2}{*}{0.77} & 57.16 & 8.08 & \multirow[b]{2}{*}{0.18} & \multirow[b]{2}{*}{0.68} \\
\hline & $\mathrm{C}$ & 55.88 & 1.92 & & & 57.81 & 2.38 & & \\
\hline \multirow{2}{*}{ Circumference of the upper arm $(\mathrm{cm})$} & $\mathrm{E}$ & 18.14 & 1.71 & \multirow{2}{*}{5.46} & \multirow{2}{*}{0.02} & 18.52 & 1.83 & \multirow{2}{*}{3.02} & \multirow[b]{2}{*}{0.09} \\
\hline & $\mathrm{C}$ & 17.23 & 1.24 & & & 17.80 & 1.32 & & \\
\hline \multirow{2}{*}{ Circumference of the lower arm $(\mathrm{cm})$} & $\mathrm{E}$ & 17.34 & 1.24 & \multirow{2}{*}{0.57} & \multirow{2}{*}{0.46} & 17.75 & 1.22 & \multirow{2}{*}{0.74} & \multirow{2}{*}{0.39} \\
\hline & $\mathrm{C}$ & 17.11 & 1.03 & & & 17.49 & 1.10 & & \\
\hline \multirow{2}{*}{ Abdominal skin fold (mm) } & $\mathrm{E}$ & 6.10 & 2.85 & \multirow{2}{*}{0.68} & \multirow{2}{*}{0.42} & 6.77 & 3.12 & \multirow{2}{*}{0.79} & \multirow{2}{*}{0.38} \\
\hline & C & 6.77 & 3.50 & & & 7.56 & 3.72 & & \\
\hline \multirow{2}{*}{ Skin fold of the back (mm) } & E & 5.41 & 1.33 & \multirow{2}{*}{0.18} & 067 & 5.78 & 1.53 & & \\
\hline & C & 5.55 & 1.27 & & 0.67 & 5.88 & 1.29 & 0.07 & 0.79 \\
\hline Skin fold of the upper arm (mm) & $\mathrm{E}$ & 9.46 & 2.33 & 6.38 & 0.01 & 10.20 & 2.18 & 725 & 001 \\
\hline & $c$ & 8.20 & 1.38 & & & 8.89 & 1.53 & & \\
\hline
\end{tabular}

$\mathrm{F}=2,52 \mathrm{P}=0,02 \quad \mathrm{~F}=2,29 \mathrm{P}=0,04$

$\mathrm{f}$ - $\mathrm{f}$-test for univariate analysis of variance, $\mathrm{AM}$ - Arithmetic mean $\mathrm{p}$ - level of statistical significance for $\mathrm{f}$

$\mathrm{S}$ - Standard deviation $\mathrm{F}-\mathrm{F}$-test for multivariate analysis of variance, $\mathrm{P}-$ level of statistical significance for $\mathrm{F}$ 
The results of multivariate analysis of variance foreight anthropometric characteristics for the final measurement, with the level of significance of $\mathrm{p}=0.04$ indicates that there were statistically significant differences between the two groups, which are reflected only in relation to the Skin fold of the upper arm, where the experimental group had a statistically better result in comparison to the control group at the level of $p=0.01$. In other variables, there were no statistically significant differences.

It can be seen (Table IV) that on the multivariate level there was no statistically significant difference between the two groups, and the results of the univariate analysis of variance (ANOVA) confirmed this fact.

The results of multivariate analysis of variance for seven motor ability for the final measurement, with the level of significance of $p=0.04$ indicates that there was statistically significant difference between the two groups, which are reflected only in relation to the $20 \mathrm{~m}$ dash, Standing broad jump and Sit-ups, where the experimental group had a statistically better result in comparison to the control group at the level of $p=0.01$. In all other variables the experimental group had better results but they were not statistically significant. The exception was the variable Standing broad jump where the control group had better but not statistically significant results.

The experimental (E) group showed statistically significant improvement of the results in almost all anthropometric variables by comparing the arithmetic mean of the initial measurement with the final measurement. In almost all variables better results were achieved on the final measure that could be inferred from the sign (-) for $t$ - test. The variable Circumference of the chest was the exception and there was a statistically significant difference Control
(C) group showed statistically significant improvement of results in almost all of the anthropometric variables by comparing the arithmetic mean of the initial measurement with the final measurement. In almost all variables better results were achieved on the final measurement that could be inferred from the sign (-) for t-test. The exception is the variable Skinfold of the back in which there was no statistically significant difference.

The experimental (E) group showed statistically significant improvements in the most of outcome variables compared with the arithmetic mean of the initial measurement compared to the final measurement. The exceptions are the variables Sit-ups where there has not been an improvement in the results and it was not statistically significant. The variable Seated straddle stretch showed better results on the final measurement but it was not that statistically significant. Of course, due to the inverse of the metric variables $20 \mathrm{~m}$ dash and Obstacle course backwards the sign is + .

In the control $(\mathrm{C})$ group there was a statistically significant improvement in results in the 4 variables $(20 \mathrm{~m}$ dash, Obstacle course backwards, Arm plate taping Standing broad jump) compared with the arithmetic mean of the initial measurement compared to the final measurement. In the other variables (Seated straddle stretch, Bent arm hang and Sit-ups), there was no statistically significant improvement in the results of the final compared to the initial measurement.

Based on these results (Table VII) multivariate analysis of covariance (MANCOVA) and univariate analysis of covariance (ANCOVA) revealed that in all the variables evaluated anthropometric characteristics there was no statistical significance at $\mathrm{p}=0.05$ or that there was no statistically significant difference between the groups.

Table IV. The results of univariate and multivariate analysis of variance motor abilities between the experimental (E) and control (C) groups at the initial measurement.

\begin{tabular}{|c|c|c|c|c|c|c|c|c|c|}
\hline \multirow{2}{*}{ VARIABLES } & \multicolumn{5}{|c|}{ INITIAL } & \multicolumn{4}{|c|}{ FINAL } \\
\hline & G & $\mathrm{AM}$ & $\mathrm{S}$ & $\mathrm{F}$ & $\mathrm{p}$ & $\mathrm{AM}$ & S & $\mathrm{f}$ & $\mathrm{p}$ \\
\hline \multirow[t]{2}{*}{$20 \mathrm{~m}$ dash $(\mathrm{s})$} & $\mathrm{E}$ & 6.00 & 0.70 & 3.05 & 0.09 & 5.37 & 0.49 & 11.48 & 0.00 \\
\hline & $\mathrm{C}$ & 6.36 & 0.89 & & & 5.89 & 0.71 & & \\
\hline \multirow[t]{2}{*}{ Obstacle course backwards (s) } & $\mathrm{E}$ & 32.74 & 1.21 & 0.64 & 0.43 & 24.98 & 7.48 & 1.31 & 0.26 \\
\hline & $\mathrm{C}$ & 30.53 & 8.85 & & & 27.33 & 8.41 & & \\
\hline \multirow[t]{2}{*}{ Arm plate tapping (freq.) } & $\mathrm{E}$ & 13.3 & 0.25 & 4.27 & 0.06 & 16.5 & 0.30 & 0.35 & 0.56 \\
\hline & $\mathrm{C}$ & 14.9 & 0.35 & & & 16.0 & 0.38 & & \\
\hline \multirow[t]{2}{*}{ Seated straddle stretch $(\mathrm{cm})$} & E & 34.4 & 0.50 & 0.02 & 0.90 & 34.7 & 0.45 & 0.56 & 0.46 \\
\hline & $\mathrm{C}$ & 34.6 & 0.73 & & & 35.8 & 0.66 & & \\
\hline \multirow[t]{2}{*}{ Standing broad jump $(\mathrm{cm})$} & E & 102.6 & 1.68 & 0.72 & 0.40 & 116.2 & 1.49 & 5.65 & 0.02 \\
\hline & $\mathrm{C}$ & 98.1 & 2.40 & & & 103.9 & 2.42 & & \\
\hline \multirow[t]{2}{*}{ Bent-arm hang (s) } & E & 19.6 & 0.69 & 0.57 & 0.45 & 20.3 & 0.57 & 2.92 & 0.09 \\
\hline & $\mathrm{C}$ & 18.0 & 0.86 & & & 17.2 & 0.83 & & \\
\hline \multirow[t]{2}{*}{ Sit-ups (freq.) } & $\mathrm{E}$ & 14.15 & 1.86 & 1.95 & 0.17 & 13.34 & 9.38 & 6.28 & 0.02 \\
\hline & $\mathrm{C}$ & 9.08 & 6.12 & & & 8.66 & 3.80 & & \\
\hline
\end{tabular}

$\mathrm{F}=2,07 \mathrm{P}=0,06 \quad \mathrm{~F}=2,35 \mathrm{P}=0,04$ 
Based on the results from Table VIII, the multivariate level of statistically significant difference between groups $\mathrm{p}=0.05$ and the results of the univariate analysis of covariance (ANCOVA), it can be concluded that in the variables $20 \mathrm{~m}$ dash, Obstacle course backwards, Arm plate tapping, Standing broad jump and Sit-ups exists a statistically significant difference at $p=0.05$ in favor of the experimental (E) group. The other two variables did not show statistically significant difference between the experimental and control group.

Table V. T-test for anthropometric variables for experimental and control group

\begin{tabular}{|c|c|c|c|c|c|c|c|c|c|c|}
\hline \multirow[t]{2}{*}{ VARIABLES } & \multicolumn{5}{|c|}{ INITIAL } & & \multicolumn{4}{|c|}{ FINAL } \\
\hline & G & $\mathrm{AM}$ & $\mathrm{S}$ & $\mathrm{t}$ & $\mathrm{p}$ & G & AM & $\mathrm{S}$ & $\mathrm{t}$ & $\mathrm{p}$ \\
\hline \multirow[t]{2}{*}{ Height (cm) } & $\mathrm{E}_{\mathrm{i}}$ & 111.48 & 4.81 & -8.63 & 0.00 & $\mathrm{Ci}$ & 111.42 & 5.79 & -8.63 & 0.00 \\
\hline & $E_{f}$ & 116.31 & 5.14 & & & $\mathrm{Cf}$ & 115.19 & 5.86 & & \\
\hline \multirow[t]{2}{*}{ Body mass (kg) } & $\mathrm{E}_{\mathrm{i}}$ & 19.95 & 2.93 & -13.87 & 0.00 & $\mathrm{Ci}$ & 19.83 & 2.34 & -13.87 & 0.00 \\
\hline & $E_{f}$ & 21.68 & 3.28 & & & $\mathrm{Cf}$ & 21.17 & 2.56 & & \\
\hline \multirow{2}{*}{$\begin{array}{l}\text { Circumference of the } \\
\text { chest }(\mathrm{cm})\end{array}$} & $\mathrm{E}_{\mathrm{i}}$ & 55.67 & 3.27 & -1.08 & 0.29 & $\mathrm{Ci}$ & 55.88 & 1.92 & -1.08 & 0.00 \\
\hline & $E_{f}$ & 57.16 & 8.08 & & & $\mathrm{Cf}$ & 57.81 & 2.38 & & \\
\hline \multirow{2}{*}{$\begin{array}{l}\text { Circumference of the } \\
\text { upper } \operatorname{arm}(\mathrm{cm})\end{array}$} & $\mathrm{E}_{\mathrm{i}}$ & 18.14 & 1.71 & -2.37 & 0.02 & $\mathrm{Ci}$ & 17.23 & 1.24 & -2.37 & 0.00 \\
\hline & $E_{f}$ & 18.52 & 1.83 & & & $\mathrm{Cf}$ & 17.80 & 1.32 & & \\
\hline \multirow{2}{*}{$\begin{array}{l}\text { Circumference of the } \\
\text { lower } \operatorname{arm}(\mathrm{cm})\end{array}$} & $\mathrm{E}_{\mathrm{i}}$ & 17.34 & 1.24 & -3.34 & 0.00 & $\mathrm{Ci}$ & 17.11 & 1.03 & -3.34 & 0.04 \\
\hline & $E_{f}$ & 17.75 & 1.22 & & & $\mathrm{Cf}$ & 17.49 & 1.10 & & \\
\hline \multirow{2}{*}{$\begin{array}{l}\text { Abdominal skin } \\
\text { fold }(\mathrm{mm})\end{array}$} & $\mathrm{E}_{\mathrm{i}}$ & 6.10 & 2.85 & -3.30 & 0.00 & $\mathrm{Ci}$ & 6.77 & 3.50 & -3.30 & 0.04 \\
\hline & $E_{f}$ & 6.77 & 3.12 & & & $\mathrm{Cf}$ & 7.56 & 3.72 & & \\
\hline \multirow{2}{*}{$\begin{array}{l}\text { Skin fold of } \\
\text { the back }(\mathrm{mm})\end{array}$} & $\mathrm{E}_{\mathrm{i}}$ & 5.41 & 1.33 & -2.88 & 0.01 & $\mathrm{Ci}$ & 5.55 & 1.27 & -2.88 & 0.10 \\
\hline & $E_{f}$ & 5.78 & 1.53 & & & $\mathrm{Cf}$ & 5.88 & 1.29 & & \\
\hline \multirow{2}{*}{$\begin{array}{l}\text { Skin fold of the upper } \\
\operatorname{arm}(\mathrm{mm})\end{array}$} & $\mathrm{E}_{\mathrm{i}}$ & 9.46 & 2.33 & -4.51 & 0.00 & $\mathrm{Ci}$ & 8.20 & 1.38 & -4.51 & 0.00 \\
\hline & $E_{f}$ & 10.20 & 2.18 & & & $\mathrm{Cf}$ & 8.89 & 1.53 & & \\
\hline
\end{tabular}

Ei - experimental group (initial), Ef - experimental group (final),

$\mathrm{Ci}$ - control group (initial), $\mathrm{Cf}$ - control group (final),

AM- arithmetic mean, $\mathrm{t}-\mathrm{t}$ test for dependent samples, $\mathrm{p}$ - statistical significance

Table VI. T-test for motor abilities for experimental and control group.

\begin{tabular}{|c|c|c|c|c|c|c|c|c|c|c|}
\hline \multirow[t]{2}{*}{ VARIABLES } & \multicolumn{5}{|c|}{ INITIAL/FINAL } & \multirow[b]{2}{*}{ G } & \multirow[b]{2}{*}{ AM } & \multirow[b]{2}{*}{$\mathrm{S}$} & \multirow[b]{2}{*}{ t } & \multirow[b]{2}{*}{$\mathrm{p}$} \\
\hline & G & $\mathrm{AM}$ & S & $\mathrm{t}$ & $\mathrm{p}$ & & & & & \\
\hline \multirow{2}{*}{$\begin{array}{l}20 \mathrm{~m} \\
\text { dash (s) }\end{array}$} & $\mathrm{E}_{\mathrm{i}}$ & 6.00 & 0.70 & 8.28 & 0.00 & $\mathrm{Ci}$ & 6.36 & 0.89 & 4.29 & 0.00 \\
\hline & $\mathrm{E}_{\mathrm{f}}$ & 5.37 & 0.49 & & & $\mathrm{Cf}$ & 5.89 & 0.71 & & \\
\hline \multirow{2}{*}{$\begin{array}{l}\text { Obstacle course } \\
\text { backwards (s) }\end{array}$} & $\mathrm{E}_{\mathrm{i}}$ & 32.74 & 12.16 & 5.93 & 0.00 & $\mathrm{Ci}$ & 30.53 & 8.85 & 3.12 & 0.00 \\
\hline & $E_{f}$ & 24.98 & 7.48 & & & $\mathrm{Cf}$ & 27.33 & 8.41 & & \\
\hline \multirow{2}{*}{$\begin{array}{l}\text { Arm plate } \\
\text { tapping (freq.) }\end{array}$} & $\mathrm{E}_{\mathrm{i}}$ & 13.3 & 0.25 & -5.59 & 0.00 & $\mathrm{Ci}$ & 14.9 & 0.35 & -2.01 & 0.05 \\
\hline & $\mathrm{E}_{\mathrm{f}}$ & 16.5 & 0.30 & & & $\mathrm{Cf}$ & 16.0 & 0.38 & & \\
\hline \multirow{2}{*}{$\begin{array}{l}\text { Seated straddle } \\
\text { stretch }(\mathrm{cm})\end{array}$} & $\mathrm{E}_{\mathrm{i}}$ & 34.4 & 0.50 & -0.54 & 0.59 & $\mathrm{Ci}$ & 34.6 & 0.73 & -1.52 & 0.14 \\
\hline & $\mathrm{E}_{\mathrm{f}}$ & 34.7 & 0.45 & & & $\mathrm{Cf}$ & 35.8 & 0.66 & & \\
\hline \multirow{2}{*}{$\begin{array}{l}\text { Standing broad } \\
\text { jump }(\mathrm{cm})\end{array}$} & $\mathrm{E}_{\mathrm{i}}$ & 102.6 & 1.68 & -5.75 & 0.00 & $\mathrm{Ci}$ & 98.1 & 2.40 & -2.68 & 0.01 \\
\hline & $\mathrm{E}_{\mathrm{f}}$ & 116.2 & 1.49 & & & $\mathrm{Cf}$ & 103.9 & 2.42 & & \\
\hline \multirow{2}{*}{$\begin{array}{l}\text { Bent-arm } \\
\text { hang (s) }\end{array}$} & $\mathrm{E}_{\mathrm{i}}$ & 19.6 & 0.69 & -0.71 & 0.48 & $\mathrm{Ci}$ & 18.0 & 0.86 & 0.64 & 0.53 \\
\hline & $\mathrm{E}_{\mathrm{f}}$ & 20.3 & 0.57 & & & $\mathrm{Cf}$ & 17.2 & 0.83 & & \\
\hline \multirow{2}{*}{$\begin{array}{l}\text { Sit-ups } \\
\text { (freq.) }\end{array}$} & $\mathrm{E}_{\mathrm{i}}$ & 14.15 & 18.64 & 0.25 & 0.80 & $\mathrm{Ci}$ & 9.08 & 6.12 & 0.43 & 0.67 \\
\hline & $\mathrm{E}_{\mathrm{f}}$ & 13.34 & 9.38 & & & $\mathrm{Cf}$ & 8.66 & 3.80 & & \\
\hline
\end{tabular}


STUPAR, D.; POPOVIC, B.; ROMANOV, R.; JANKOVIC, M.; JEZDIMIROVIC, T. \& MEDJEDOVIC, B. The effects of specific exercise program on anthropometric characteristics and motor abilities of preschool children. Int. J. Morphol., 35(3):1050-1057, 2017.

Table VII. Results of multivariate and univariate analysis of covariance between the experimental (E) and control (C) group on the final measurement.

\begin{tabular}{|c|c|c|c|c|c|}
\hline VARIABLES Gr. & & EMM & $\mathrm{Se}$ & $\mathrm{f}$ & $\mathrm{p}$ \\
\hline \multirow{2}{*}{ Height $(\mathrm{cm})$} & $\mathrm{E}$ & 115.90 & 0.59 & 0.09 & 0.77 \\
\hline & $\mathrm{C}$ & 115.63 & 0.61 & & \\
\hline \multirow[t]{2}{*}{ Body mass (kg) } & $\mathrm{E}$ & 21.61 & 0.14 & 2.81 & 0.10 \\
\hline & $\mathrm{C}$ & 21.24 & 0.15 & & \\
\hline \multirow[t]{2}{*}{ Circumference of the chest $(\mathrm{cm})$} & $\mathrm{E}$ & 57.18 & 1.15 & 0.11 & 0.74 \\
\hline & $\mathrm{C}$ & 57.78 & 1.19 & & \\
\hline \multirow[t]{2}{*}{ Circumference of the upper arm $(\mathrm{cm})$} & $\mathrm{E}$ & 18.25 & 0.16 & 0.45 & 0.51 \\
\hline & $\mathrm{C}$ & 18.08 & 0.17 & & \\
\hline \multirow[t]{2}{*}{ Circumference of the lower arm $(\mathrm{cm})$} & $\mathrm{E}$ & 17.67 & 0.15 & 0.16 & 0.69 \\
\hline & $\mathrm{C}$ & 17.58 & 0.16 & & \\
\hline \multirow[t]{2}{*}{ Abdominal skin fold (mm) } & $\mathrm{E}$ & 7.10 & 0.31 & 0.05 & 0.83 \\
\hline & $\mathrm{C}$ & 7.21 & 0.32 & & \\
\hline \multirow[t]{2}{*}{ Skin fold of the back (mm) } & $\mathrm{E}$ & 5.82 & 0.18 & 0.01 & 0.93 \\
\hline & $\mathrm{C}$ & 5.84 & 0.19 & & \\
\hline \multirow[t]{2}{*}{ Skin fold of the upper arm (mm) } & $\mathrm{E}$ & 9.76 & 0.19 & 1.83 & 0.18 \\
\hline & $\mathrm{C}$ & 9.36 & 0.20 & & \\
\hline
\end{tabular}

Table VIII. Results of multivariate and univariate analysis of covariance for motor abilities between the experimental (E) and control (C) group on the final measurement.

\begin{tabular}{llrrll}
\hline VARIABLES Gr. & & \multicolumn{1}{c}{ EMM } & \multicolumn{1}{l}{ Se } & \multicolumn{1}{l}{ f } & \multicolumn{1}{l}{ P } \\
\hline 20 m dash (s) & E & 55.01 & 0.08 & 4.52 & $\mathbf{0 . 0 4}$ \\
& C & 57.48 & 0.08 & & \\
Obstacle course backwards (s) & E & 24.52 & 0.95 & 5.12 & $\mathbf{0 . 0 3}$ \\
& C & 27.81 & 0.99 & & \\
Arm plate tapping (freq.) & E & 17.06 & 0.05 & 4.25 & $\mathbf{0 . 0 4}$ \\
& C & 15.42 & 0.05 & & \\
Seated straddle stretch (cm) & E & 35.05 & 0.06 & 0.22 & 0.64 \\
Standing broad jump (cm) & C & 35.50 & 0.07 & & \\
& E & 114.62 & 0.23 & 6.75 & $\mathbf{0 . 0 1}$ \\
Bent-arm hang (s) & C & 105.62 & 0.24 & & \\
Sit-ups (freq.) & E & 19.52 & 0.10 & 0.93 & 0.34 \\
& C & 18.07 & 0.10 & & \\
& E & 13.14 & 1.35 & 4.28 & $\mathbf{0 . 0 4}$ \\
& C & 8.86 & 1.41 & & \\
\hline
\end{tabular}

\section{DISCUSSION}

Some researchers in their experimental programs got positive influence on the morphological features of preschool children (Trajkovski et al., 2014), but in others works they were able to influence on the rate of skin folds among the four year old (Trajkovski-Visic et al., 2008). This program did not significantly improve the anthropological dimension, especially skin folds, and it was logical because in order to achieve positive effects on the reduction of skin folds, it was necessary to make the reduction in the diet and to have longer sessions of aerobic character. On the other hand, among children it was shown that the parameters such as cholesterol or percentage of body fat associated with maximal oxygen uptake (okic et al., 2010). We cannot expect the same proportional increase VO2 max, in the training of children as well as in the training of adults. Those changes in younger (preschool) children aware less than half than in older children ages 10 - 13 (Stupar \& Popovic, 2013). It was noted that preschool children aerobic endurance was not yet sufficiently developed. The halls are of a relatively small size and therefore long-distance running or cycling and inline skates could not have been performed. The only possibility to apply these aerobic activities was in May when the trainings are held outdoors. 
In numerous studies which have analyzed the effects of different experimental models motor program on the motor status of children (Sääkslahti et al., 2001; Trajkovski-Visic, 2004; Giagazoglou et al., 2008; Zivcic et al., 2008; Stupar, 2011; Donath et al., 2014; da Rocha Queiroz et al., 2014; Krneta et al., 2014; Krneta et al., 2015; Stupar et al., 2015) the positive effects on the development of the motor skills of preschool children was identified. It can be seen (Table VIII) that the experimental (E) group in the final measurement showed statistically significant improvements in the most of the outcome variables compared with the arithmetic mean of the initial measurement. A well-planned curriculum, activities including the varied and interesting exercises which operate primarily in the coordination but also speed, agility, balance, strength and other motor skills, has helped in improving the most of motor abilities of the experimental group. The various sprint exercises with fast changes of direction for the development of speed and agility, quick and accurate manipulation of various balls of different shapes, sizes, weights, in standing position, during movement, alone or in couples, improvement of coordination and speed unless, alternative arm movements and lots of jumps, leaps, bounces, etc. are included, which significantly improves the extent of the explosive power of the lower extremities of the children. Of course this is not the only reason for improving the results of the motor abilities measured in this study. The activities at the pool are one of the reasons for better development of motor skills of the experimental group. Control group of children from state kindergartens were rarely present at the pool, although in their curriculum there were planned activities on the water. The benefits of such training are multiple. If we take into account that some organs of the child (brain, endocrine glands, liver) complete their development before the age of 5 and the fact that physical exercise and movement in the water contribute to their harmonious maturation (Ivanovic, 2008) then we can notice the importance of early involvement of children in water activities.

\section{CONCLUSION}

In relation to the anthropometric characteristics and longitudinal and transverse dimensions of the body, this model kinetic activity did not show statistically significant differences for the control group, which indicates that this model of practice is not used to improve the morphological characteristics in order to reduce skin wrinkles, weight, volume, which is most easily corrected by extended aerobic work. Except in May, while training outdoors, children did not have the opportunity to be exposed to prolonged aerobic work in the gym.
Model of kinetic activity that was used in experimental group showed greater effects compared to the control group in the space of motoric abilities although the number of training sessions (twice per week for $60 \mathrm{~min}$.) gave better results. The authors conclude that the results would certainly be improved if the number of trainings was higher (three to five times a week), which is organizationally hardly feasible (hall procuration).

A large number of studies, which have dealt with the comparison of different models of practice for preschool children, usually take for the control group children from state kindergartens. In almost all studies the experimental group has achieved better results because of the experimental program. Therefore, this model of practice (or similar) should be applied in all state kindergartens.

\section{ACKNOWLEDGEMENTS}

This study was performed as part of the project entitled, "Integrated development, physical activity and aberrant behaviors of preschool children", conducted by the Faculty of Sport and Physical Education, University of Novi Sad, Novi Sad, Serbia, and financed by the Ministry of Education, Science and Technological Development of Republic of Serbia. The authors would like to thank them for their support.

STUPAR,D.; POPOVIC, B.; ROMANOV, R.; JANKOVIC, M.; JEZDIMIROVIC, T. \& MEDJEDOVIC, B. Efectos de un programa de ejercicios específicos sobre las características antropométricas y las habilidades motrices de los niños de edad preescolar. Int. J. Morphol., 35(3):1050-1057, 2017.

RESUMEN: Con el fin de determinar los efectos de un programa de ejercicios específicos sobre las características antropométricas y las habilidades motrices de los niños en edad preescolar, se aplicó una batería de 8 medidas antropométricas y 7 pruebas motrices. El presente estudio se realizó en una muestra de 60 niños en edad preescolar (31 en el grupo experimental y 29 en el grupo de control), de 4 a 5 años. Los niños en este estudio forman parte del proyecto implementado por la Facultad de Deporte y Educación Física de Novi Sad. Los datos obtenidos se analizaron mediante análisis multivariante de covarianza (MANCOVA). Se puede concluir que la aplicación de modelos experimentales y de control de ejercicios resultó en una mejora sustancial de ciertas habilidades motoras en el grupo experimental en comparación con el grupo control. En cuanto a la antropometría, no hubo diferencias estadísticamente significativas entre los grupos. De hecho, el valor práctico de este trabajo es analizar el modelo de actividades cinéticas, que como tal puede aplicarse a todos los clubes y escuelas que trabajan con niños en edad preescolar y escolar. 
PALABRAS CLAVE: Medidas antropométricas; Habilidades Motrices; Edad preescolar; Escuela de deportes.

\section{REFERENCES}

Bala, G. Morphological characteristics of preschool children. In: Bala, G (Ed.). Anthropological characteristics and abilities of preschool children. Novi Sad, Fakultet Sportai Fizickog Vaspitanja, 2007. pp.33-65.

Bala, G. Sports school. Novi Sad, Samostalno autorsko izdanje, 2002.

Bala, G. Structure and development of morphologic and motor dimensions in children of SAP Vojvodina. Novi Sad, Faculty of Physical Culture, University of Novi Sad, 1981.

Bala, G.; Popovic, B. \& Stupar, D. Necessary modifications of some standard motor tests for preschool children. Proceedings of the 10th International Symposium Sport, Physical Activity and Youth Health. Novi Sad, Univerzitet u Novom Sadu, Novosadski maraton, 2002.

da Rocha Queiroz, D.; Ré, A. H. N. \& dos Santos Henrique, R.; de Sousa Moura, M. \& Cattuzzo, M. T. Participation in sports practice and motor competence in preschoolers. Motriz (Rio Claro), 20(1):26-32, 2014

Dokic, Z.; Veljovic, D.; Stojanovic, V. M. \& Medjedovic, B. Aerobic endurance training and the level of aerobic capacity of young people. TIMS Acta, 4:43-53, 2010

Donath, L.; Imhof, K.; Roth, R. \& Zahner, L. Motor skill improvement in preschoolers: How effective are activity cards? Sports, 2(4):140-51, 2014.

Giagazoglou, P.; Karagianni, O.; Sidiropoulou, M. \& Salonikidis, K. Effects of the characteristics of two different preschool-type setting on children's gross motor development. Eur. Psychomot. J., 1(1):54-60, 2008.

Ismail, A. H. \& Gruber, J. J. Integrated Development - Motor Aptitude and Intellectual Perfomance. Columbus, Charles E. Merrill Books, 1971.

Ivanovic, M. Training children in swimming.Valjevo, Samostalno autorsko izdanje, 2008

Kamenov, E. Basis of a Model of Educational Work with Preschool Children. Novi Sad: Odsek za pedagogiju Filozofskog fakulteta u Novom Sadu, Visa skola za obrazovanje vaspitaca u Kikindi, 1995.

Krneta, Z.; Casals, C.; Bala, G.; Madic, D.; Pavlovic, S. \& Drid, P. Can kinesiological activities change "pure" motor development in preschool children during one school year? Coll.Antropol., 39 Suppl., 1:35-40, 2015.

Krneta,Z.; Drid, P.; Jaksic, D.; Bala, G.; Stojanovic, M. \& Ostojic, S. Effects of kinesiological activity on preschool children's motor abilities. Sci. Sports, 29 Suppl.:S48, 2014.

Kurelic, N.; Momirovic, K., Stojanovic, M., Sturm, J., Radojevic, \& Viskic-Stalec, N. The Structure and Development of Morphological and Motoric Dimensions of Youth. Beograd, Institute for Scientific Research of the Faculty of Physical Education, 1975.

Lepes, J.; Halasi, S.; Mandaric, S. \& Tanovic, N. Relation between body composition and motor abilities of children up to 7 years of age. Int. J. Morphol., 32(4):1179-83, 2014.

Lohman, T. G.; Roche, A. F. \& Martorell, R. Anthropometric Standardization Reference Manual. Champaign, Human Kinetics Books, 1988

Sääkslahti, A.; Numminen, P.; Varsal, V. \& Välimäki, I. Effects of intervention on children's motor development during four year follow-up. Cologne, 6th Annual congres of the European College of Sport Science - 15th Congress of the German Society of Sport Science, 2001. pp.78.

Stupar, D. \& Popovic, B. Preschool Teachers Vs. Physical Education Teachers: Who is More Efficient at Developing Motor Abilities of Preschool Children? In: Madic, D. (Ed.). Proceedings 3rd International Scientific Conference Exercise and quality of life. Novi Sad, Faculty of Sport and Physical Education, 2013. pp.239-44.

Stupar, D. Differences in anthropometric characteristics and motor abilities between boys and girls age 7: Meta-analysis. TIMS Acta, 6(2):57-64, 2012.

Stupar, D. M.; Fratric, F. F., Nesic, M., Rubin, P. \& Medjedovic, B. The effects of an experimental program of speed development on preschool children. Facta Univ. Ser. Phys. Educ. Sport, 13(1):139-48, 2015.
Stupar, D. The Effects of Two Models of Exercise of Development of Motor Abilities Among Preschool Children. Novi Sad, Faculty of Sport and Physical Education, 2011.

Trajkovski-Visic, B. The impact of changes in the sports program of morphological and motor characteristics of children aged 4. Magistarski rad. Zagreb, Kinezioloski fakultet Sveucilista u Zagrebu, 2004.

Trajkovski-Visic, B.; Misigoj-Durakovic, M.; Zivcic, K. \& Plavec, D Effects of sports-activity programs in reducing subcutaneous fat in four-year-olds. Zagreb, Proceedings Book of the 5th International Scientific Conference on Kinesiology "Kinesiology Research Trends and Applications", 2008. pp.570-3.

Trajkovski, B.; Misigoj-Durakovic, M. \& Plavec, D. Differences in morphological characteristics among preschool children with regard to the involvement in exercise programs and connection to the parents' nutritional condition. Sport Sci., 7(1):15-9, 2014.

Zivcic, K.; Trajkovski-Visic, B. \& Sentderdi, M. Changes in some of the motor abilities of preschool children (age four). Facta Univ. Ser. Phys. Educ. Sport, 6(1):41-50, 2008.

\section{Correspondence author:}

Dusan Stupar

Educons University

Faculty of Sport and Tourism

TIMS, Radnicka str. 30 A, 21000

Novi Sad

SERBIA

\section{E-mail: dusan.stupar@tims.edu.rs}

Received:22-02-2017

Accepted:24-04-2017 